\title{
Kalanchoe (Crassulaceae) as invasive aliens in China - new records, and actual and potential distribution
}

\section{Zhi-Qiang Wang, Daniel Guillot, Ming-Xun Ren and Jordi López-Pujol}

Z.-Q. Wang, Key Laboratory for Bio-resources and Eco-environment, College of Life Sciences, Sichuan University, Chengdu 610065, Sichuan, People's Republic of China - D. Guillot, Botanic Garden, University of Valencia. C/ Quart, 82, 46008 Valencia, Spain - M.-X. Ren, Key Laboratory of Protection and Development Utilization of Tropical Crop Germplasm Resources (Hainan University), Ministry of Education \& College of Horticulture and Landscape Architecture, Hainan University, 570228 Haikou, Hainan, People's Republic of China - J. López-Pujol (jlopez@ibb.csic.es), Botanic Institute of Barcelona (IBB-CSIC-ICUB).Passeig del Migdia, s/n, 08038 Barcelona, Spain 
[Abstract]

Kalanchoe daigremontiana and $K$. delagoensis are reported for the first time from Sichuan and Hainan (China), respectively. For the first, a new population located in Chengdu downtown has been found, being the first one in western China and thus representing a significant range extension of this species within the country. For K. delagoensis, a new population has been observed in the Old Quarter of Haikou, being the southernmost population of this species in China. The distribution area of both species in China is updated through review of the literature, as well as that of their putative hybrid, K. $\times$ houghtonii. For the case of $K$. delagoensis, its potential range has also been estimated through a niche-based modelling approach. Finally, a key to taxa of Kalanchoe in China is provided. 


\section{Introduction}

The genus Kalanchoe (including Bryophyllum) has nearly 150 species distributed in Madagascar (its center of diversity), E and S Africa, Arabia, and tropical and SE Asia (Descoigns 2003). A few species, however, have spread beyond their native areas given their use as ornamentals, and today are global invaders. The best known examples are, in addition to $K$. pinnata (the 'air plant'), K. daigremontiana and $K$. delagoensis. These two latter are regarded as serious pests in several countries such as Australia, South Africa, and the United States (Moran 2009, Walters et al. 2011, Palmer and Rafter 2012). The invasion capabilities of both $K$. daigremontiana and $K$. delagoensis are enhanced by a vigorous clonal growth through pseudobulbils that arise from the margin of their leaves (hence the popular name 'mother of millions' or 'mother of thousands'); this strategy is also shared by their hybrid form, $K . \times$ houghtonii (Guerra-García et al. 2015). This hybrid taxon was firstly noted by A. D. Houghton in the 1930s, and arises spontaneously when these two species occur together (Akulova-Barlow 2009). In southern Europe, this hybrid is even more invasive than its parental species, and in some cities such as Barcelona it has already become a common component of the urban landscape (Guillot et al. 2014).

According to Flora of China, only six taxa belonging to the genus Kalanchoe are present in China (including Taiwan): K. ceratophylla, K. garambiensis, K. integra, K. pinnata, K. spathulata var. annamica, and K. tashiroi ( $\mathrm{Fu}$ and Ohba 2001). In addition, only $K$. pinnata was generally included in the lists or compendiums on naturalized and invasive plants in China published during the last decade (e.g. Wu et al. 2004, 2010a, Lin et al. 2007, Weber et al. 2008, Xu et al. 2012). However, $K$. delagoensis was already included in the list of invasive plants for the whole China of Fang and Wan (2009), in the list of naturalized plants for Taiwan (Wu et al. 2010a), and in the list of naturalized plants of China of Jiang et al. (2011). In addition, $K$. daigremontiana is also listed, together with $K$. delagoensis, in the most recent list of invasive alien plants in China (Yan et al. 2014).

In the course of a field investigation in tropical and subtropical areas of China, we observed one population of $K$. daigremontiana in the city of Chengdu (Sichuan Province, SW China) and one population of $K$. delagoensis in the city of Haikou

(Hainan Island, S China). The objectives of this work were to (i) evaluate the 
significance of these findings within the context of the Chinese alien flora, (ii) estimate the current distribution area of $K$. daigremontiana, $K$. delagoensis, and its hybrid form $K . \times$ houghtonii, and know if the new findings constitute substantial range extensions in China, (iii) estimate the potential range of $K$. delagoensis through a niche-based modeling approach, and (iv) provide a key to taxa of Kalanchoe in China given that the three species studied here ( $K$. daigremontiana, $K$. delagoensis and $K . \times$ houghtonii) seem to be well established and, thus, they should be regarded as members of the flora of China.

\section{Material and Methods}

The new localities were photographed (using a digital camera Finepix HS50 EXR; Fujifilm, Tokyo, Japan) and georeferenced. Dried herbarium specimens were deposited at the reference regional herbaria (SZ for the population of $K$. daigremontiana from Chengdu; HUTB for the population of $K$. delagoensis from Haikou). Co-occurring species (if present) were also recorded.

To estimate the range of the three species of Kalanchoe (K. daigremontiana, $K$. delagoensis, K. $\times$ houghtonii) in China and, thus, to evaluate the significance of the newly discovered populations, an extensive literature search was conducted and included all major regional taxonomic works (Flora of China, Flora Reipublicae Popularis Sinicae, Flora of Taiwan, Flora of Hong Kong), checklists (both at national and regional levels), lists and catalogues of naturalized and invasive plants, research articles, and grey literature. Major databases and information systems were also checked, including citizen science projects: Global Biodiversity Information Facility (GBIF; www.gbif.org/), Chinese Virtual Herbarium (CVH; www.cvh.ac.cn), Taiwan Biodiversity Information Facility (TaiBIF; www.taibif.tw), iNaturalist (www.inaturalist.org), Chinese Field Herbarium (CFH; www.cfh.ac.cn), and Plant Photo Bank of China (PPBC; www.plantphoto.cn).

The potential range was only determined for $K$. delagoensis because for the other two taxa the number of georeferenced wild occurrences in China were not enough to get reliable models centered in the country $(<5$; see Pearson et al. 2007). To do it, we employed the maximum entropy algorithm, as implemented in MaxEnt v. 3.3 (Phillips 
et al. 2006). In total, we obtained 39 presence records (wild occurrences) for $K$. delagoensis (Supplementary material Appendix 1, Table A1). A set of 19 bioclimatic variables at 30 arc-sec $(\sim 1 \mathrm{~km})$ resolution covering the distribution range (and neighboring areas) under current conditions (1950-2000) were downloaded from the WorldClim website (www.worldclim.org; Hijmans et al. 2005). Given that the establishment and spread of $K$. delagoensis is often facilitated by human disturbance (Queensland Government 2007, Walters et al. 2011, Guerra-García et al. 2015), an additional variable, the Human Footprint (an index of anthropogenic impacts on the environment; Sanderson et al. 2002) was added to the set of studied variables (and downloaded from the Center for International Earth Science Information Network at Columbia University; http://sedac.ciesin.columbia.edu). After a correlation analysis in a random sample of 1000 points within the study area, we selected a smaller set of eight not highly correlated variables $(r<0.8)$ : annual mean temperature (bio1), mean diurnal temperature range (bio2), isothermality (bio3), temperature annual range (bio7), annual precipitation (bio12), precipitation of driest month (bio14), precipitation seasonality (bio15), and human footprint. The selection of variables from pairs or groups of highly correlated $(r \geq 0.8$ ) ones was done on the basis of their relative contribution to the model (percent contribution, jackknife tests of variable importance).

Replicate runs (50) of MaxEnt (using the 'subsampling' method) were performed to ensure reliable results. Model performance was assessed using the area under the curve (AUC) of the receiver operating characteristic plot, with $20 \%$ of the localities randomly selected to test the model. AUC scores may range between 0.5 (randomness) and 1 (exact match), with those above 0.9 indicating a good performance of the model (Swets 1988). Ecological niche modelling (ENM) prediction was visualized in ArcGIS v. 9.3 (ESRI, Redlands, CA, USA), with the aid of Hawth's Analysis Tools (Beyer 2004).

\section{Results and Discussion}

Kalanchoe daigremontiana Raym.-Hamet \& H. Perrier (1914, p. 128)

Based on the same type: Bryophyllum daigremontianum A. Berger (1930, p. 412). 
Voucher specimens: China. Sichuan: Chengdu, Wuhou District, on a building façade, growing together with Crassula ovata, several individuals (some flowering), $495 \mathrm{~m}$ a.s.1., $30.64^{\circ} \mathrm{N}, 104.08^{\circ} \mathrm{E}, 4$ June 2015, Z.-Q. Wang and J. López-Pujol (SZ 00356561, SZ 00356562) (Supplementary material Appendix 1, Fig. A1).

This species is a biennial diploid $(2 n=34$; Baldwin 1949) herb, that is easily distinguishable from the other taxa of the genus that are present in China by having simple leaves that are ovate, oblong-ovate to long-triangular, with dentate margins, and strongly auriculate to strongly cordate leaf base (rarely sub-peltate; see the identification key, below, and Supplementary material Appendix 1, Fig. A1). Kalanchoe daigremontiana is native to SW Magadascar (Descoigns 2003), although at present it is widely naturalized in several tropical, subtropical or dry-climate countries (Invasive Species Compendium 2015a). In some areas is regarded as invasive, such as in Australia (Weeds Australia 2015) and in SE United States (Moran 2009). In recent years it has been detected in some locations of southern Europe, including Italy (Celesti-Grapow et al. 2009), Portugal (Almeida and Freitas 2006), and Spain (Sanz et al. 2004, 2011, Guillot et al. 2015b).

According to our literature search, the species is present as wild in at least two provinces of China (Fig. 1). As shown in the Supplementary material Appendix 1 (Table A1), the species has been reported from two nearby locations in Fujian Province (SE China) and from Bawangling Nature Reserve in Hainan Island. There are also doubtful old herbarium records from another location in Fujian (Gulangyu Island) as well as from Guizhou and Yunnan. However, we cannot attribute them to $K$. daigremontiana with certainty, as the specimens are incomplete or badly preserved (Supplementary material Appendix 1, Table A1). The species has also been included in the Check List of Hong Kong Plants (Hong Kong Herbarium 2004), although we have failed to find herbarium specimens or other references providing precise locations within this special administrative region of China. The population of $K$. daigremontiana detected by us should be regarded as the first one in western China (or, at least, the first of Sichuan) and, thus, represents a significant range extension of this species within the country (Fig. 1). It is a small population located in the downtown of the city of Chengdu (on a small roof at a building façade), and it seems to be well-established [it contains several mature (flowering) individuals along with many juvenile (vegetative) ones and 
seedlings; Supplementary material Appendix 1, Fig. A1]. Although K. daigremontiana is probably the least invasive of the three taxa of Kalanchoe studied here, it may become naturalized in many areas of the country as it is widely cultivated (Fig. 1 and Supplementary material Appendix 1, Table A1).

Kalanchoe delagoensis Eckl. \& Zeyh. (1837, p. 305)

Based on the same type: Bryophyllum delagoense (Eckl. \& Zeyh.) Schinz (1900, p. $38)$.

Taxonomic synonyms: Bryophyllum tubiflorum Harv. (1862, p. 380) - Kalanchoe verticillata Scott Elliot (1891, p. 14) - Kalanchoe tubiflora (Harvey) Raym.-Hamet (1912, p. 41) - Bryophyllum verticillatum A. Berger (1930, p. 411).

Voucher specimens: China. Hainan: Haikou, Old Quarter, at the façade of some old houses, $10 \mathrm{~m}$ a.s.1., $20.04^{\circ} \mathrm{N}, 110.34^{\circ} \mathrm{E} 7$ August 2015, J. López-Pujol and M.-X. Ren K1 (HUTB) (Supplementary material Appendix 1, Fig. A2).

This species is a biennial or a short perennial tetraploid $(2 n=68$; Baldwin 1949), that can be distinguished by its narrowly linear leaves from the other taxa of the genus (Supplementary material Appendix 1, Fig. A2). Another characteristic trait is that bulbils can be found only in the apex (see the identification key, below). As for $K$. daigremontiana, $K$. delagoensis is native to Madagascar (to the central and southern parts of the island). It is the most widely distributed among the three species of Kalanchoe studied here, as it occurs throughout the Americas (including the Caribbean islands), southern Europe, most of Africa, several locations in Asia (China, India), and Oceania (Micronesia, Melanesia, Polynesia, Australia, and New Zealand) (Guillot et al., 2015a, Invasive Species Compendium, 2015b). Kalanchoe delagoensis is behaving as invasive in some regions, including Australia (Queensland Government 2007, Palmer and Rafter 2012), China (Yan et al. 2014), South Africa (Walters et al. 2011), and SE United States (Moran 2009).

In contrast to $K$. daigremontiana, $K$. delagoensis is a relatively common plant in China. Our search for occurrences in the literature has indicated that this succulent plant 
is present as wild in at least four provinces of the mainland: Anhui, Fujian, Guangdong, and Guangxi (Fig. 1 and Supplementary material Appendix 1, Table A1). In addition, it is present in many locations throughout Taiwan Island (where it arrived in the 1960s; $\mathrm{Wu}$ et al. 2010b), as well as in Hong Kong (as for K. daigremontiana, the species has also been included in the Check List of Hong Kong Plants; Hong Kong Herbarium 2004). To our knowledge, the population discovered by us in Haikou City is the first one for Hainan Island and, thus, the southernmost population of $K$. delagoensis in China (Fig. 1). The population is composed by dozens of vegetative individuals located at the façade (in wall cracks or on cornices) of several old two-storey buildings located on the Old Quarter of Haikou City (Supplementary material Appendix 1, Fig. A2), sometimes accompanied by Talinum paniculatum (Jacq.) Gaertn. Like in Haikou, most of the pictures hosted in the checked databases (such as PPBC or CFH) are showing $K$. delagoensis naturally growing on roofs and other parts of the buildings (in some cases forming dense monospecific carpets). It seems that it was already a common element of the roofs of Guangzhou City (Canton) more than one decade ago (Jian et al. 2004). The fact that most of the observations of the species are within urban environments indicates that the species in China is still in the first stages of invasion, as probably occurs with the other two taxa of Kalanchoe (see above and below).

Regarding the ENM model, the AUC score averaged across 50 runs was very high (mean $\pm \mathrm{SD}, 0.990 \pm 0.006$ ), which supported the predictive power of the model. According to the jackknife tests, mean diurnal temperature range (bio2), temperature annual range (bio7), and annual mean temperature (bio1) were the most informative for predicting the niche of the species in China. The ENM model (Fig. 1) shows that the potential distribution of $K$. delagoensis in China is limited to the coastal southern region (from southern Jiangsu to Guangxi), including the two large islands of China (Hainan and Taiwan) and also a region in Sichuan/Chongqing. Some small areas throughout subtropical and tropical China are also suitable. It should be noted that $K$. delagoensis is cultivated in some areas where it does not occur in the wild but that contain suitable habitat (e.g. Nanning in southern Guangxi; Supplementary material Appendix 1, Table A1), paving thus the way for new invasions. To some extent, we believe that the ENM model of $K$. delagoensis can be extrapolated to the other two conspecific taxa studied here, as they are usually found in the same habitats (pavement cracks, building roofs, waste places, fence lines, vacant lots, disturbed grasslands/woodlands) and, in fact, they often co-occur (e.g. Ward 2006, Guerra-García et al. 2015). Moreover, for the Iberian 
Peninsula, the ENMs of the three Kalanchoe taxa were almost identical (Guillot et al. 2014, 2015a, b).

\section{Kalanchoe $\times$ houghtonii D. B. Ward (2006, p. 94)}

Based on the same type: Bryophyllum houghtonii (D. B. Ward) P. I. Forst. (2006, p. $383)$.

This species is a monocarpic short perennial herb, morphologically relatively similar to $K$. daigremontiana but distinguishable by the leaf base (usually neither auriculate nor cordate in $K . \times$ houghtonii). However, as leaves of $K . \times$ houghtonii may rarely present small auricules or can be weakly cordate (see the identification key, below), confusions with $K$. daigremontiana are relatively common. In fact, until the species was not formally described in 2006 (Ward 2006), many of its occurrences were assigned erroneously to $K$. daigremontiana (e.g. Moran 2009). This hybrid taxa was firstly described by A. D. Houghton in the 1930s (obtained by experimental crosses in his nursery in California); although it was named by him as Kalanchoe tubimontanum (Houghton 1935), it was not validly published. According to Shaw (2008), there were originally two clones in cultivation, a fertile tetraploid and a sterile triploid, but it seems that the original plants were triploid $(2 n=51$; Baldwin 1949). Kalanchoe $\times$ houghtonii was observed in the wild in Australia as soon as 1965 (AVH 2015), and the plant has been reported throughout America (including the Caribbean islands), southern Europe, Asia (India), and Oceania (apart from Australia, in some Polynesian islands and in New Zealand) (Guillot et al. 2014). In some of these areas it has become a strong invader, such as in Queensland, Australia (Queensland Government 2007) and Venezuela (erroneously identified as K. daigremontiana; Herrera et al. 2012).

Until now, there were no records of $K . \times$ houghtonii in China contained in floras or in articles in scientific journals. Our extensive research including grey literature, internet databases, and citizen science sites has evidenced that the hybrid is present in, at least, three different regions (Fig. 1); in the mainland, there is one PPBC record from Jinjiang City (Quanzhou, Fujian Province); interestingly, in this same location the PPBC also hosts pictures of $K$. daigremontiana (Supplementary material Appendix 1, 
Table A1), supporting our hypothesis that the ENM of $K$. delagoensis may be partly extrapolated to the other two Kalanchoe taxa. Kalanchoe $\times$ houghtonii is also present in Taiwan Island, in an urban park of Taichung City; finally, the species has also been observed at least in two different locations in Hong Kong SAR (Fig. 1). In addition, the two doubtful occurrences of $K$. daigremontiana from Guizhou and Yunnan might be actually $K . \times$ houghtonii (see Supplementary material Appendix 1, Table A1), although the antiquity of the records (1960 and 1936, respectively) makes this possibility unlikely (as this hybrid was firstly noted in the 1930 s in the United States). Since $K . \times$ houghtonii is cultivated in several areas of southern and eastern China (Fig. 1 and Supplementary material Appendix 1, Table A1), the list of occurrences may increase in the coming years.

\section{Key to species of Kalanchoe in China}

1. Leaves first simple, later pinnate to 3 - to 5-foliate or at middle of stem pinnately lobed.

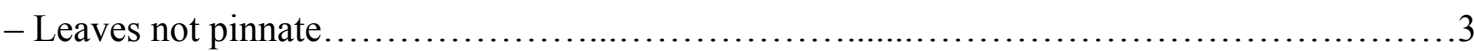

2. Leaflets linear to linear-lanceolate, corolla yellow, styles $2-4 \mathrm{~mm}$. K. ceratophylla

- Leaflets ovate to oblong or oblong-circular; corolla green below, red to greenish-reddish above; styles $22-30 \mathrm{~mm}$. K. pinnata

3. Leaves narrowly linear, terete; bulbils only at the apex.... K. delagoensis

- Leaves ovate, oblong, triangular, deltoid, spatulate or linear-oblong, elliptic or obovate; bulbils absent or bulbils appearing along the margins. .4

4. Leaves linear-oblong; flowers yellow with linear spots

K. spathulata var. annamica (K. annamica)

- Leaves ovate, oblong, long-triangular, deltoid, elliptic, obovate or spatulate .................. 5

5. Margins dentate with numerous bulbils on the teeth ..................................... 6

- Margins entire or crenate ..................................................................

6. Leaf base strongly auriculate, to strongly cordate, rarely sub-peltate.

K. daigremontiana

- Leaf base without auricles, or if present, very small, not or weakly cordate, not peltate, lamina gradually narrowing into petiole.

.K. $\times$ houghtonii

7. Lamina $1-2.8 \times 0.3-1.3 \mathrm{~cm}$, tip rounded, mucronate, margins entire.

K. garambiensis

- Lamina more than $2.8 \mathrm{~cm}$ long $\times 1.3 \mathrm{~cm}$ wide .8 
8. Leaves green above, pale below, tip broadly triangular, margins irregularly crenate

K. tashiroi

- Leaves light grey-green, tip obtuse, margins entire or crenate. K. integra (K. deficiens)

Acknowledgments - We thank S.-J. Ling and S.-J. Qi for their aid in the collection of $K$. delagoensis from Haikou City. Z.-Q. Wang has benefited from China Postdoctoral Science Foundation funded project (2015M582547) and a postdoctoral fund of Sichuan University.

\section{References}

Akulova-Barlow, Z. 2009. Kalanchoe. - Cactus Succul. J., 81: 268-276.

Almeida, J. D. de and Freitas, H. 2006. Exotic flora of continental Portugal - a reassessment. - Bot. Complut. 30: 117-130.

AVH 2015. Australia's Virtual Herbarium, Council of Heads of Australasian Herbaria. $<$ http://avh.chah.org.au>, accessed 10 August 2015.

Baldwin, J. T. 1949. Hybrid of Kalanchoe daigremontiana and K. verticillata. - Bull. Torrey Bot. Club, 76: 343-345.

Berger, A. 1930. Crassulaceae. - In: Engler, A. and Prantl, K. (eds.), Die natürlichen pflanzenfamilien (2nd ed.). Vol 18a. Wilhelm Engelmann, Leipzig, pp. 352-485

Beyer, H. L. 2004. Hawth's analysis tools for ArcGIS. $<$ http://www.spatialecology.com/htools>, accessed 5 August 2015.

Celesti-Grapow, L. et al. 2009. Inventory of the non-native flora of Italy. - Plant Biosyst. 143: 386-430.

Descoigns, B. 2003. Kalanchoe. - In: Eggli, U. (ed.), Illustrated handbook of succulent plants: Crassulaceae. Springer-Verlag, Berlin, pp. 143-181.

Ecklon, C. F. and Zeyher, C. L. P. 1837. Enumeratio plantarum Africae australis extratropicae. Vol. 3. - Hamburg, Perthes \& Besser. 
Fang, J. and Wan, F. 2009. Invasive species and their impacts on endemic ecosystems in China - In: Kohli, R. K. et al. (eds.), Invasive plants and forest ecosystems. CRC Press, Boca Raton, pp. 157-175.

Forster, P. I. 2006. Bryophyllum $\times$ houghtonii (D.B.Ward) P.I.Forst., a new combination in Crassulaceae for the hybrid Mother of Millions. - Austrobaileya $7(2): 383$.

Fu, K. and Ohba, I. 2001. Crassulaceae. - In: Wu, Z. Y. and Raven, P. H. (eds.), Flora of China. Vol. 8 (Brassicaceae through Saxifragaceae). Science Press, Beijing, and Missouri Botanical Garden Press, St. Louis, pp. 202-268.

Guerra-García, A. et al. 2015. Invasion of Kalanchoe by clonal spread. - Biol. Invasions 17: $1615-1622$.

Guillot, D. et al. 2014. Kalanchoe × houghtonii 'Garbí'. - Bouteloua 19: 99-128.

Guillot, D. et al. 2015a. Kalanchoe delagoensis 'Morvedre'. - Bouteloua 22: 64-75.

Guillot, D. et al. 2015b. Kalanchoe daigremontiana Raym.-Hamet \& H. Perrier 'Iberian Coast'. - Bouteloua 21: 35-48.

Hamet, R. 1912. Observations sur le Kalanchoe tubiflora nom. nov. - Beih. Bot. Centralbl. 29(2): 41-44.

Hamet, R. and Perrier de la Bâthie, H. 1914. Nouvelle contribution à l'étude des Crassulacées malgaches. - Ann. Mus. Colon. Marseille, sér. 3, 2: 113-203.

Harvey, W. H. 1862. Crassulaceae. - In: Harvey, W. H. and Sonder, O. W. (eds.), Flora Capensis. Vol. 2 (Leguminosae to Loranthaceae). Hodges, Smith \& Co., Dublin, pp. $327-380$.

Herrera, I. et al. 2012. Plantlet recruitment is the key demographic transition in invasion by Kalanchoe daigremontiana. - Popul. Ecol. 54: 225-237.

Hijmans, R. J. et al. 2005. Very high resolution interpolated climate surfaces for global land areas. - Int. J. Climatol. 25: 1965-1978.

Hong Kong Herbarium 2004. Check List of Hong Kong Plants 2004. - Agriculture, Fisheries and Conservation Department, the Government of Hong Kong Special Administrative Region, Hong Kong.

Houghton, A. D. 1935. An interesting hybrid. - Cactus Succul. J. 7: 44.

Invasive Species Compendium 2015a. Kalanchoe daigremontiana (devil's backbone), datasheet. <http://www.cabi.org/isc/datasheet/115049>, accessed 11 August 2015. Invasive Species Compendium 2015b. Kalanchoe delagoensis (chandelier plant), datasheet. <http://www.cabi.org/isc/datasheet/115050>, accessed 13 August 2015. 
Jian, S. et al. 2004. The plant species naturally growing on the roof of buildings in Guangzhou City. - Chin. Wild Plant Resour. 23: 35-37 (in Chinese).

Jiang, H. et al. 2011. Naturalization of alien plants in China. - Biodivers. Conserv. 20: $1545-1556$.

Lin, W. et al. 2007. Fast economic development accelerates biological invasions in China. - PLoS One 2: e1208.

Moran, R. V. 2009. Bryophyllum. - In: Flora of North America Editorial Committee (eds.), Flora of North America North of Mexico. Vol. 8. Oxford University Press, New York and Oxford, pp. 158-161.

Palmer, B. and Rafter, M. 2012. Bryophyllum delagoense (Ecklon \& Zeher) Schinz, mother-of-millions. - In: Julien, M. et al. (eds.), Biological control of weeds in Australia. CSIRO Publishing, Melbourne, pp. 99-107.

Pearson, R. G. et al. 2007. Predicting species distributions from small numbers of occurrence records: a test case using cryptic geckos in Madagascar. - J. Biogeogr. 34: $102-117$.

Phillips, S. J. et al. 2006. Maximum entropy modeling of species geographic distributions. - Ecol. Model. 190: 231-259.

Queensland Government 2007. Mother of millions. Queensland Government, Department of Natural Resources and Mines. Brisbane (Queensland, Australia). $<$ http://www.southwestnrm.org.au/sites/default/files/uploads/ihub/queenslanddepartment-primary-industries-and-fisheries-2007-mother-millionsbryophyllum.pdf>, accessed August 2015.

Sanderson, E. W. et al. 2002, The human footprint and the last of the wild. - BioScience 52: 891-904.

Sanz, M. et al. 2004. Atlas de las plantas alóctonas invasoras en España. - Dirección General para la Biodiversidad, Ministerio de Medio Ambiente, Madrid.

Sanz, M. et al. 2011. La flora alóctona de la Comunidad Valenciana (España). - Bot. Complut. 35: 97-130.

Schinz, H. and Junod, H. A. 1900. Zur kenntnis der pflanzenwelt der Delagoa-Bay. Mém. Herb. Boissier 10: 25-79. 1900

Scott Elliot, G. F. 1891. New and little-known Madagascar plants. - J. Linn. Soc., Bot. 29(197): 1-67.

Shaw, J. M. H. 2008. An investigation of the cultivated Kalanchoe daigremontiana group, with a checklist of Kalanchoe cultivars. - Hanburyana 3: 17-79. 
Swets, J. A., 1988. Measuring the accuracy of diagnostic systems. - Science 240: 12851293.

Walters, M. et al. 2011. Naturalised and invasive succulents of southern Africa. Abc Taxa, vol. 11. - The Belgian Development Cooperation, Brussels.

Ward, D. B. 2006. A name for a hybrid Kalanchoe now naturalized in Florida. - Cactus Succul. J. 78: 92-95.

Weber, E. et al. 2008. Invasive alien plants in China: diversity and ecological insights. Biol. Invasions 10: 1411-1429.

Weeds Australia 2015. Noxious weed list for Australian states and territories. $<$ http://www.weeds.org.au/docs/weednet6.pdf $>$, accessed 9 August 2015.

$\mathrm{Wu}$, S.-H. et al. 2004. Catalogue of the naturalized flora of Taiwan. - Taiwania 49: 1631.

Wu, S.-H. et al. 2010a. Patterns of plant invasions in China: taxonomic, biogeographic, climatic approaches and anthropogenic effects. - Biol. Invasions 12: 2179-2206.

$\mathrm{Wu}$ S.-H. et al. 2010b. Insights of the latest naturalized flora of Taiwan: Change in the past eight years. - Taiwania 55: 139-159.

$\mathrm{Xu}, \mathrm{H}$. et al. 2012. An inventory of invasive alien species in China. - NeoBiota 15: 126.

Yan, X. et al. 2014. The categorization and analysis on the geographic distribution patterns of Chinese alien invasive plants. - Biodivers. Sci. 22: 667-676 (in Chinese).

Supplementary material (Appendix NJBXXXXX at $<$ www.nordicjbotany.org/readers/appendix $>$ ). Appendix 1. 
Figure 1. Top (A) and bottom (C) maps, location of wild (filled circles) and cultivated (plus symbol) localities found in China of Kalanchoe daigremontiana and $K . \times$ houghtonii, respectively. Empty circles represent the doubtful occurrences (see Supplementary material Appendix 1, Table A1). Middle map (B), location of wild (filled circles) and cultivated (plus symbol) localities of $K$. delagoensis, and potential distribution in China as probability of occurrence. Predicted distribution probabilities are shown in each 30 arc-sec pixel. We used the maximum training sensitivity plus specificity logistic threshold (mean value $=0.0324$ ) to discriminate between suitable and unsuitable habitat. 
Wang, Z.-Q., Guillot, D., Ren, M.-X., and López-Pujol. J. 2016. Kalanchoe (Crassulaceae) as invasive aliens in China - new records, and actual and potential distribution. - Nordic J. Bot. doi: 10.1111/njb.01052

\section{Supplementary material Appendix 1}

Figure A1. Detail of the population of Kalanchoe daigremontiana from downtown Chengdu (Sichuan Province). The inset is a close view of the leaves. Pictures: J. LópezPujol.

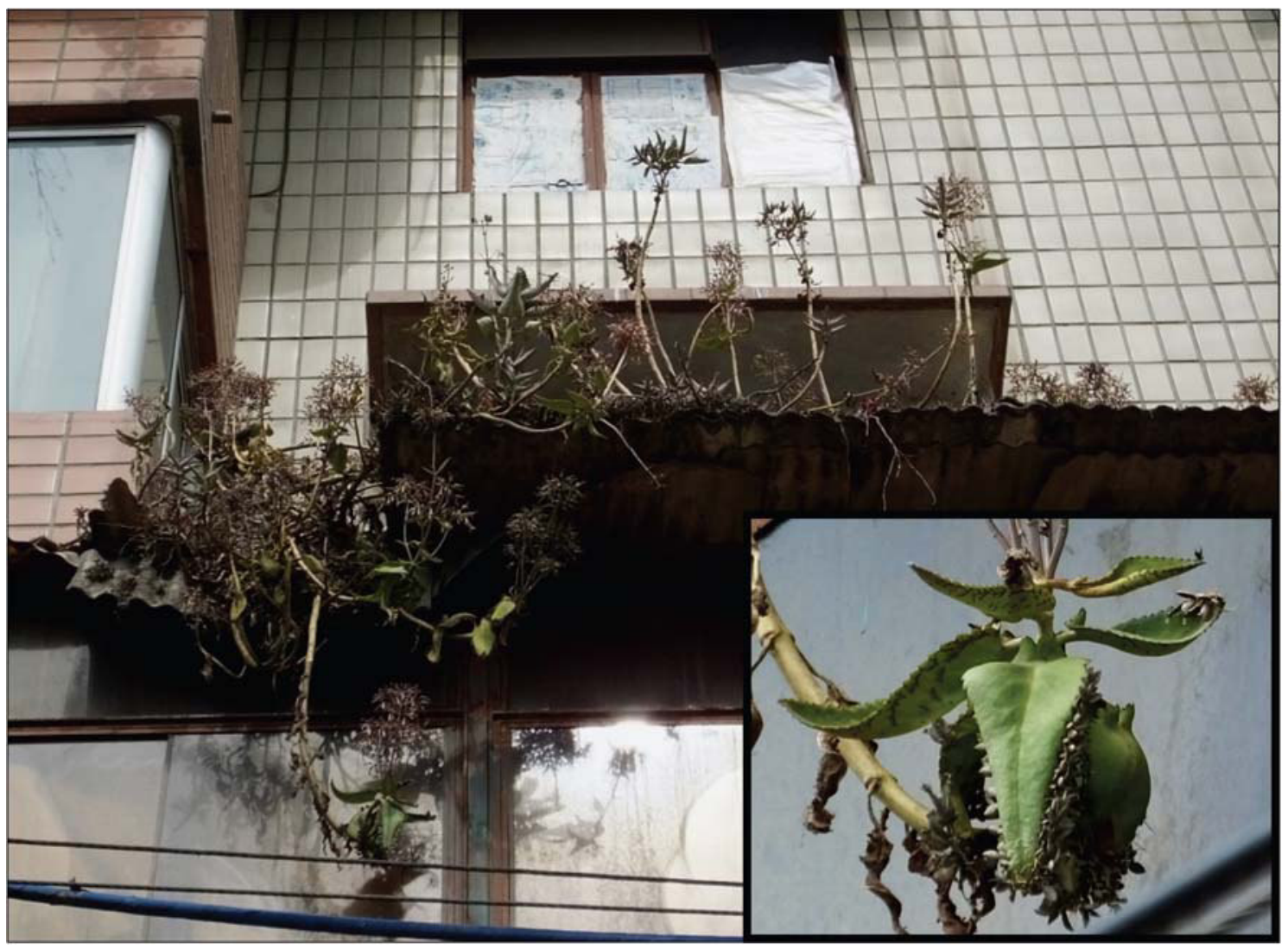


Figure A2. Some individuals of Kalanchoe delagoensis growing in a building cornice, in Haikou City (Hainan Island). The inset is showing the details of the leaves (from an individual transplanted from the population that is now cultivated in Hainan University). Pictures: J. López-Pujol (general) and M.-X. Ren (inset).

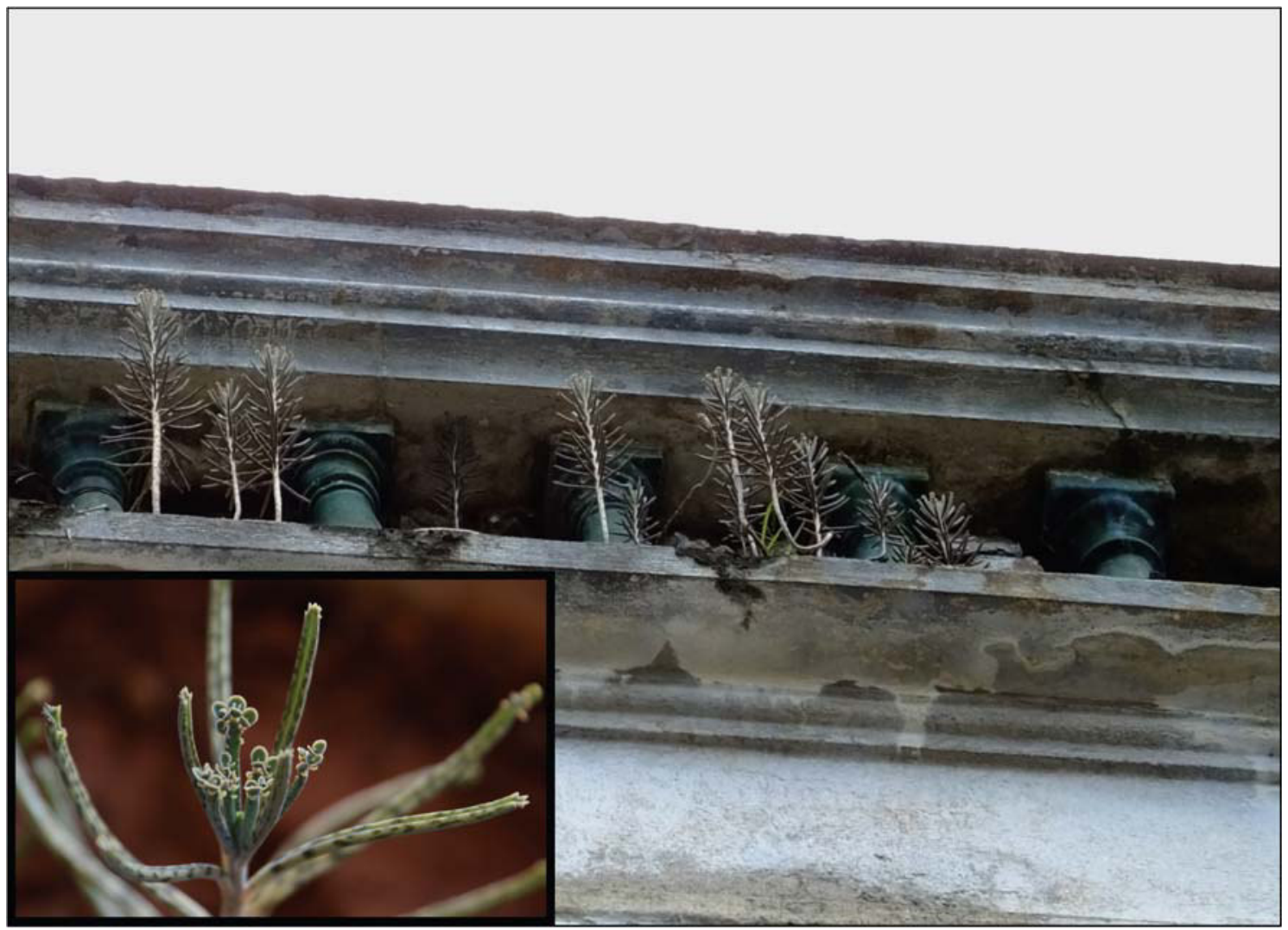


Table A1. List of wild and cultivated localities found in China of Kalanchoe daigremontiana, K. delagoensis, and K. $\times$ houghtonii.

\begin{tabular}{|c|c|c|c|c|c|}
\hline Species & Locality & $\begin{array}{l}\text { Geographic } \\
\text { coordinates }\end{array}$ & $\begin{array}{l}\text { Wild/Cult } \\
\text { ivated }\end{array}$ & Source & Additional information \\
\hline K. daigremontiana & Hefei (Anhui) & $31.79^{\circ} \mathrm{N}, 117.25^{\circ} \mathrm{E}$ & $\mathrm{C}$ & PPBC & http://www.plantphoto.cn/tu/1535078 \\
\hline K. daigremontiana & $\begin{array}{l}\text { Beijing Botanical Garden } \\
\text { (Chinese Academy of } \\
\text { Sciences), Beijing } \\
\text { (Beijing Municipality) }\end{array}$ & $39.99^{\circ} \mathrm{N}, 116.21^{\circ} \mathrm{E}$ & $\mathrm{C}$ & $\begin{array}{l}\text { J. López- } \\
\text { Pujol, pers. } \\
\text { obs. }\end{array}$ & Observed in 2003 and in 2015 \\
\hline K. daigremontiana & $\begin{array}{l}\text { Fujian Normal } \\
\text { University, Fuzhou } \\
\text { (Fujian) }\end{array}$ & $26.04^{\circ} \mathrm{N}, 119.31^{\circ} \mathrm{E}$ & $\mathrm{C}$ & $\mathrm{CFH}$ & $\begin{array}{l}\text { http://wwww.cfh.ac.cn/album/ShowPhoto.asp } \\
\text { x?photoid=6efbb37d-e2b8-4ff3-a91f- } \\
\text { 63386a291679 }\end{array}$ \\
\hline K. daigremontiana & $\begin{array}{l}\text { Chongwuzhen, Quanzhou } \\
\text { (Fujian) }\end{array}$ & $24.89^{\circ} \mathrm{N}, 118.92^{\circ} \mathrm{E}$ & $\mathrm{W}$ & PPBC & http:/虚Www.plantphoto.cn/tu/39953 \\
\hline K. daigremontiana & $\begin{array}{l}\text { Jinjiang, Quanzhou } \\
\text { (Fujian) }\end{array}$ & $24.57^{\circ} \mathrm{N}, 118.60^{\circ} \mathrm{E}$ & $\mathrm{W}$ & PPBC & http://wwww.plantphoto.cn/tu/1058563 \\
\hline K. daigremontiana? ${ }^{1}$ & $\begin{array}{l}\text { Gulangyu Island, Xiamen } \\
\text { (Fujian) }\end{array}$ & $24.45^{\circ} \mathrm{N}, 118.06^{\circ} \mathrm{E}$ & $\mathrm{W}$ & $\mathrm{CVH}$ & $\begin{array}{l}\text { AU } 008740 \text { [Herbarium specimen]; labeled } \\
\text { as “K. Kgremontianum"; } \\
\text { http://www.cvh.ac.cn/spm/AU/008740 }\end{array}$ \\
\hline K. daigremontiana & $\begin{array}{l}\text { Huli District, Xiamen } \\
\text { (Fujian) }\end{array}$ & $24.50^{\circ} \mathrm{N}, 118.14^{\circ} \mathrm{E}$ & $\mathrm{C}$ & $\mathrm{CVH}$ & $\begin{array}{l}\text { PE } 01268604 \text { [Herbarium specimen]; } \\
\text { http://www.cvh.ac.cn/spm/PE/01268604 }\end{array}$ \\
\hline K. daigremontiana? ${ }^{2}$ & $\begin{array}{l}\text { Xiamen Park, Xiamen } \\
\text { (Fujian) }\end{array}$ & $24.27^{\circ} \mathrm{N}, 118.06^{\circ} \mathrm{E}$ & $\mathrm{C}$ & $\mathrm{CVH}$ & $\begin{array}{l}\text { AU } 008739 \text { [Herbarium specimen]; labeled } \\
\text { as "K. } K \text { gremontianum"; } \\
\text { http://Wwww.cvh.ac.cn/spm/AU/008739 }\end{array}$ \\
\hline K. daigremontiana & Lanzhou (Gansu) & $36.05^{\circ} \mathrm{N}, 103.83^{\circ} \mathrm{E}$ & $\mathrm{C}$ & PPBC & http://www.plantphoto.cn/tu/389790 \\
\hline K. daigremontiana & $\begin{array}{l}\text { Lutianzhen, Conghua } \\
\text { (Guangdong) }\end{array}$ & $23.81^{\circ} \mathrm{N}, 113.95^{\circ} \mathrm{E}$ & $\mathrm{C}$ & PPBC & $\begin{array}{l}\text { http://Wwww.plantphoto.cn/tu/296524; } \\
\text { http://WWww.plantphoto.cn/tu/410442 }\end{array}$ \\
\hline K. daigremontiana? ${ }^{3}$ & $\begin{array}{l}\text { Former Chengguan } \\
\text { People's Commune, } \\
\text { Luodian (Guizhou) }\end{array}$ & $25.43^{\circ} \mathrm{N}, 106.75^{\circ} \mathrm{E}$ & $\mathrm{W}$ & $\mathrm{CVH}$ & $\begin{array}{l}\text { IBSC } 0143086 \text { [Herbarium specimen]; } \\
\text { labeled as Bryophyllum sp.; } \\
\text { http://www.cvh.ac.cn/spm/IBSC/0143086 }\end{array}$ \\
\hline K. daigremontiana & $\begin{array}{l}\text { Bawangling National } \\
\text { Nature Reserve (Hainan) }\end{array}$ & $\begin{array}{l}18.95-19.18^{\circ} \mathrm{N} \\
109.05-109.28^{\circ} \mathrm{E}\end{array}$ & $\mathrm{W}$ & $\begin{array}{l}\text { Hu et al. } \\
(2011)\end{array}$ & Journăl article \\
\hline K. daigremontiana & Kaifeng (Henan) & $34.82^{\circ} \mathrm{N}, 114.32^{\circ} \mathrm{E}$ & $\mathrm{C}$ & PPBC & http://www.plantphoto.cn/tu/388895 \\
\hline
\end{tabular}




\begin{tabular}{|c|c|c|c|c|c|}
\hline K. daigremontiana & Hong Kong SAR & $\begin{array}{l}22.15-22.56^{\circ} \mathrm{N} \\
113.84-114.44^{\circ} \mathrm{E}\end{array}$ & W & $\begin{array}{l}\text { Hong Kong } \\
\text { Herbarium } \\
\text { (2004) }\end{array}$ & Book \\
\hline K. daigremontiana & $\begin{array}{l}\text { Huazhong Agricultural } \\
\text { University, Wuhan } \\
\text { (Hubei) }\end{array}$ & $30.48^{\circ} \mathrm{N}, 114.35^{\circ} \mathrm{E}$ & $\mathrm{C}$ & PPBC & http://www.plantphoto.cn/tu/1823077 \\
\hline K. daigremontiana & $\begin{array}{l}\text { Wuhan Botanical Garden, } \\
\text { Wuhan (Hubei) }\end{array}$ & $30.54^{\circ} \mathrm{N}, 114.41^{\circ} \mathrm{E}$ & $\mathrm{C}$ & PPBC & http://شwww.plantphoto.cn/tu/1754784 \\
\hline K. daigremontiana & Wuxi (Jiangsu) & $31.49^{\circ} \mathrm{N}, 120.31^{\circ} \mathrm{E}$ & $\mathrm{C}$ & PPBC & http://Rwww.plantphoto.cn/tu/471450 \\
\hline K. daigremontiana & $\begin{array}{l}\text { Ganjingzi District, Dalian } \\
\text { (Liaoning) }\end{array}$ & $38.93^{\circ} \mathrm{N}, 121.55^{\circ} \mathrm{E}$ & $\mathrm{C}$ & РPBC & http://勒ww.plantphoto.cn/tu/1085848 \\
\hline K. daigremontiana & $\begin{array}{l}\text { Chengwu, Heze } \\
\text { (Shandong) }\end{array}$ & $34.95^{\circ} \mathrm{N}, 115.89^{\circ} \mathrm{E}$ & $\mathrm{C}$ & PPBC & http:/墭www.plantphoto.cn/tu/ 1871865 \\
\hline K. daigremontiana & $\begin{array}{l}\text { Licheng District, Jinan } \\
\text { (Shandong) }\end{array}$ & $36.71^{\circ} \mathrm{N}, 117.09^{\circ} \mathrm{E}$ & $\mathrm{C}$ & РPBC & http://wwww.plantphoto.cn/tu/1886293 \\
\hline K. daigremontiana & $\begin{array}{l}\text { Zoucheng, Jining } \\
\text { (Shandong) }\end{array}$ & $35.41^{\circ} \mathrm{N}, 116.96^{\circ} \mathrm{E}$ & $\mathrm{C}$ & РPBC & http://Wwww.plantphoto.cn/tu/1895968 \\
\hline K. daigremontiana & $\begin{array}{l}\text { Shinan District, Qingdao } \\
\text { (Shandong) }\end{array}$ & $36.07^{\circ} \mathrm{N}, 120.39^{\circ} \mathrm{E}$ & $\mathrm{C}$ & РPBC & http://www www.plantphoto.cn/tu/1502177 \\
\hline K. daigremontiana & $\begin{array}{l}\text { Zhaozhuang University, } \\
\text { Shizhong (Shandong) }\end{array}$ & $34.90^{\circ} \mathrm{N}, 117.53^{\circ} \mathrm{E}$ & $\mathrm{C}$ & PPBC & http:/ \\
\hline K. daigremontiana & $\begin{array}{l}\text { Jinjiang District, } \\
\text { Chengdu (Sichuan) }\end{array}$ & $30.58^{\circ} \mathrm{N}, 104.14^{\circ} \mathrm{E}$ & $\mathrm{C}$ & РPBC & 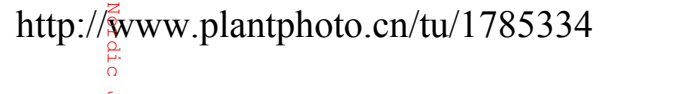 \\
\hline K. daigremontiana & $\begin{array}{l}\text { Wuhou District, } \\
\text { Chengdu (Sichuan) }\end{array}$ & $30.64^{\circ} \mathrm{N}, 104.08^{\circ} \mathrm{E}$ & $\mathbf{W}$ & This work & $\begin{array}{l}\text { SZ-00356561, SZ-00356562 [Herbarium } \\
\text { specimen] }\end{array}$ \\
\hline K. daigremontiana & $\begin{array}{l}\text { Tianjin (Tianjin } \\
\text { Municipality) }\end{array}$ & $39.08^{\circ} \mathrm{N}, 117.20^{\circ} \mathrm{E}$ & $\mathrm{C}$ & РPBC & http://wwww.plantphoto.cn/tu/1943466 \\
\hline K. daigremontiana & $\begin{array}{l}\text { Xiqing District, Tianjin } \\
\text { (Tianjin Municipality) }\end{array}$ & $39.14^{\circ} \mathrm{N}, 117.01^{\circ} \mathrm{E}$ & $\mathrm{C}$ & РPBC & 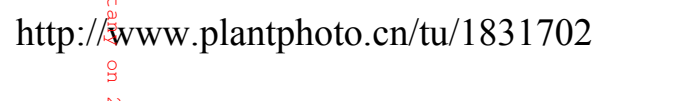 \\
\hline K. daigremontiana $?^{4}$ & $\begin{array}{l}\text { The Original Forest Park, } \\
\text { Jinhong (Yunnan) }\end{array}$ & $22.03^{\circ} \mathrm{N}, 100.88^{\circ} \mathrm{E}$ & W & $\mathrm{CVH}$ & $\begin{array}{l}\text { NAS } 0331669 \text { [Herbarium specimen]; } \\
\text { labeled as Bryophyllum pinnatum; } \\
\text { http://www.cvh.ac.cn/spm/NAS/NAS } 00331 \\
669\end{array}$ \\
\hline
\end{tabular}




\begin{tabular}{|c|c|c|c|c|c|}
\hline K. daigremontiana & $\begin{array}{l}\text { Kunming Botanical } \\
\text { Garden, Kunming } \\
\text { (Yunnan) }\end{array}$ & $25.14^{\circ} \mathrm{N}, 102.74^{\circ} \mathrm{E}$ & $\mathrm{C}$ & PPBC & http://www.plantphoto.cn/tu/2039405 \\
\hline K. daigremontiana & $\begin{array}{l}\text { Garden of Forestry } \\
\text { Bureau, Urumqi } \\
\text { (Xinjiang) } ?^{5}\end{array}$ & $43.80^{\circ} \mathrm{N}, 87.60^{\circ} \mathrm{E}$ & $\mathrm{C}$ & $\mathrm{CVH}$ & $\begin{array}{l}\text { XJBI } 00015178 \text { [Herbarium specimen]; } \\
\text { http://www.cvh.ac.cn/spm/XJBI/00015178 }\end{array}$ \\
\hline K. daigremontiana & $\begin{array}{l}\text { Xihu District, Hangzhou } \\
\text { (Zhejiang) }\end{array}$ & $30.23^{\circ} \mathrm{N}, 120.14^{\circ} \mathrm{E}$ & $\mathrm{C}$ & PPBC & http://wwww.plantphoto.cn/tu/1338852 \\
\hline K. daigremontiana & $\begin{array}{l}\text { Qingyuan, Lishui } \\
\text { (Zhejiang) }\end{array}$ & $27.62^{\circ} \mathrm{N}, 119.06^{\circ} \mathrm{E}$ & $\mathrm{C}$ & PPBC & 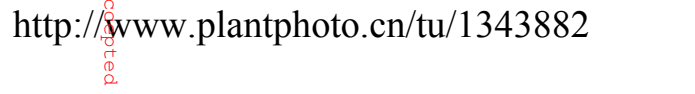 \\
\hline K. daigremontiana & $\begin{array}{l}\text { Linhai, Taizhou } \\
\text { (Zhejiang) }\end{array}$ & $28.86^{\circ} \mathrm{N}, 121.15^{\circ} \mathrm{E}$ & $\mathrm{C}$ & PPBC & 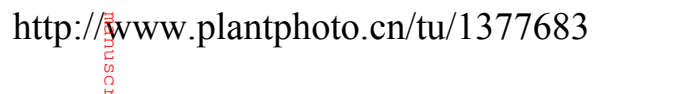 \\
\hline K. $\times$ houghtonii & $\begin{array}{l}\text { Jinjiang, Quanzhou } \\
\text { (Fujian) }\end{array}$ & $24.57^{\circ} \mathrm{N}, 118.60^{\circ} \mathrm{E}$ & $\mathrm{W}$ & PPBC & http:/㫋www.plantphoto.cn/tu/1089955 \\
\hline K. $\times$ houghtonii & $\begin{array}{l}\text { Hanyingcun, Zhangzhou } \\
\text { (Fujian) }\end{array}$ & $23.66^{\circ} \mathrm{N}, 117.20^{\circ} \mathrm{E}$ & $\mathrm{C}$ & $\mathrm{CFH}$ & $\begin{array}{l}\text { http://www.cfh.ac.cn/album/ShowPhoto.asp } \\
\text { x?photoid=bb15159c-0aa6-48cb-8f05- } \\
\text { 9c138ad42b3f }\end{array}$ \\
\hline K. $\times$ houghtonii & $\begin{array}{l}\text { Huazhou, Maoming } \\
\text { (Guangdong) }\end{array}$ & $21.73^{\circ} \mathrm{N}, 110.72^{\circ} \mathrm{E}$ & $\mathrm{C}$ & PPBC & http://www.plantphoto.cn/tu/970321 \\
\hline K. $\times$ houghtonii & $\begin{array}{l}\text { Kadoorie Farm and } \\
\text { Botanical Garden, New } \\
\text { Territories (Hong Kong } \\
\text { SAR) }\end{array}$ & $22.43^{\circ} \mathrm{N}, 114.12^{\circ} \mathrm{E}$ & $\mathrm{C}$ & PPBC & http:/鷹www.plantphoto.cn/tu/1535926 \\
\hline K. $\times$ houghtonii & $\begin{array}{l}\text { Sai Kung Country Park, } \\
\text { New Territories (Hong } \\
\text { Kong SAR) }\end{array}$ & $22.40^{\circ} \mathrm{N}, 114.35^{\circ} \mathrm{E}$ & W & PPBC & http://岱ww.plantphoto.cn/tu/2031813 \\
\hline K. $\times$ houghtonii & $\begin{array}{l}\text { Yuen Long District, New } \\
\text { Territories (Hong Kong } \\
\text { SAR) }\end{array}$ & $22.42^{\circ} \mathrm{N}, 114.08^{\circ} \mathrm{E}$ & W & iNaturalist & $\begin{array}{l}\text { https:///Www.inaturalist.org/observations/90 } \\
7947\end{array}$ \\
\hline K. $\times$ houghtonii & $\begin{array}{l}\text { Nanjing Botanical } \\
\text { Garden, Nanjing } \\
\text { (Jiangsu) }\end{array}$ & $32.05^{\circ} \mathrm{N}, 118.83^{\circ} \mathrm{E}$ & $\mathrm{C}$ & PPBC & http://帒ww.plantphoto.cn/tu/1825236 \\
\hline K. $\times$ houghtonii & Mudan, Heze (Shandong) & $35.23^{\circ} \mathrm{N}, 115.50^{\circ} \mathrm{E}$ & $\mathrm{C}$ & $\mathrm{PPBC}$ & http://wwww.plantphoto.cn/tu/1869094 \\
\hline
\end{tabular}




\begin{tabular}{|c|c|c|c|c|c|}
\hline K. $\times$ houghtonii & Yuchi, Nantou (Taiwan) & $23.85^{\circ} \mathrm{N}, 120.93^{\circ} \mathrm{E}$ & $\mathrm{C}$ & PPBC & http://www.plantphoto.cn/tu/1206796 \\
\hline K. $\times$ houghtonii & $\begin{array}{l}\text { Aofengshan Park, } \\
\text { Taichung (Taiwan) }\end{array}$ & $24.27^{\circ} \mathrm{N}, 120.59^{\circ} \mathrm{E}$ & $\mathrm{W}$ & ---- & $\begin{array}{l}\text { http://nc.kl.edu.tw/bbs/showthread.php?t=4 } \\
5086\end{array}$ \\
\hline K. $\times$ houghtonii & $\begin{array}{l}\text { Binhai District, Tianjin } \\
\text { (Tianjin Municipality) }\end{array}$ & $39.03^{\circ} \mathrm{N}, 117.69^{\circ} \mathrm{E}$ & $\mathrm{C}$ & PPBC & http://www.plantphoto.cn/tu/1777115 \\
\hline K. $\times$ houghtonii & $\begin{array}{l}\text { Kunming Botanical } \\
\text { Garden, Kunming } \\
\text { (Yunnan) }\end{array}$ & $25.14^{\circ} \mathrm{N}, 102.74^{\circ} \mathrm{E}$ & $\mathrm{C}$ & PPBC & $\begin{array}{l}\text { http://www.plantphoto.cn/tu/2039295, } \\
\text { http://wwww.plantphoto.cn/tu/1023964 }\end{array}$ \\
\hline K. $\times$ houghtonii & $\begin{array}{l}\text { Xishuangbanna Tropical } \\
\text { Botanical Garden, } \\
\text { Menglun (Yunnan) }\end{array}$ & $21.93^{\circ} \mathrm{N}, 101.25^{\circ} \mathrm{E}$ & $\mathrm{C}$ & $\mathrm{CVH}$ & $\begin{array}{l}\text { HITBC } 103168 \text { [Herbarium specimen]; } \\
\text { labeled as Kalanchoe tubiflora; } \\
\text { http://局ww.cvh.ac.cn/spm/HITBC/103168 }\end{array}$ \\
\hline K. $\times$ houghtonii & $\begin{array}{l}\text { Garden of Zhejiang } \\
\text { Agriculture and Forestry } \\
\text { University, Lin'an } \\
\text { (Zhejiang) }\end{array}$ & $30.25^{\circ} \mathrm{N}, 119.73^{\circ} \mathrm{E}$ & $\mathrm{C}$ & PPBC & http:/席www.plantphoto.cn/tu/2007289 \\
\hline K. delagoensis & $\begin{array}{l}\text { Huangshan Scenic Area, } \\
\text { Huangshan (Anhui) }\end{array}$ & $30.13^{\circ} \mathrm{N}, 118.18^{\circ} \mathrm{E}$ & $\mathrm{W}$ & Wu (2012) & $\begin{array}{l}\text { Master Thesis, Anhui Agricultural } \\
\text { University }\end{array}$ \\
\hline K. delagoensis & $\begin{array}{l}\text { Beijing Botanical Garden, } \\
\text { Beijing (Beijing } \\
\text { Municipality) }\end{array}$ & $40.00^{\circ} \mathrm{N}, 116.21^{\circ} \mathrm{E}$ & $\mathrm{C}$ & $\mathrm{CFH}$ & $\begin{array}{l}\text { http://www.cfh.ac.cn/album/ShowPhoto.asp } \\
\text { x?photoid=56376eea-561a-43b2-a6a6- } \\
\text { 322bb317a633 }\end{array}$ \\
\hline K. delagoensis & $\begin{array}{l}\text { Fujian Normal } \\
\text { University, Fuzhou } \\
\text { (Fujian) }\end{array}$ & $26.04^{\circ} \mathrm{N}, 119.31^{\circ} \mathrm{E}$ & $\mathrm{C}$ & PPBC & $\begin{array}{l}\text { http://www.plantphoto.cn/tu/536884; } \\
\text { http://Wwww.plantphoto.cn/tu/822485 }\end{array}$ \\
\hline K. delagoensis & $\begin{array}{l}\text { Jincheng, Great Kinmen } \\
\text { Island (Fujian) }\end{array}$ & $24.43^{\circ} \mathrm{N}, 118.32^{\circ} \mathrm{E}$ & $\mathrm{W}$ & ---- & $\begin{array}{l}\text { http://Wwww.panoramio.com/photo/4591194 } \\
0\end{array}$ \\
\hline K. delagoensis & $\begin{array}{l}\text { Jinhanxiang, Jiaocheng } \\
\text { (Fujian) }\end{array}$ & $26.68^{\circ} \mathrm{N}, 119.51^{\circ} \mathrm{E}$ & $\mathrm{W}$ & PPBC & http://Wwww.plantphoto.cn/tu/455661 \\
\hline K. delagoensis & $\begin{array}{l}\text { Shuangdi Overseas } \\
\text { Chinese Farm, Longhai } \\
\text { (Fujian) }\end{array}$ & $24.40^{\circ} \mathrm{N}, 117.72^{\circ} \mathrm{E}$ & $\mathrm{C}$ & PPBC & http://wwww.plantphoto.cn/tu/501306 \\
\hline K. delagoensis & $\begin{array}{l}\text { Ningde Normal } \\
\text { University, Ningde } \\
\text { (Fujian) }\end{array}$ & $26.64^{\circ} \mathrm{N}, 119.54^{\circ} \mathrm{E}$ & $\mathrm{W}$ & $\mathrm{CFH}$ & $\begin{array}{l}\text { http://wwww.cfh.ac.cn/album/ShowPhoto.asp } \\
\text { x?photoid=c9a49618-2b58-4009-9b2c- } \\
\text { dd9f05f89146 }\end{array}$ \\
\hline
\end{tabular}




\begin{tabular}{|c|c|c|c|c|c|}
\hline K. delagoensis & $\begin{array}{l}\text { Jinjiang, Quanzhou } \\
\text { (Fujian) }\end{array}$ & $24.58^{\circ} \mathrm{N}, 118.60^{\circ} \mathrm{E}$ & $\mathrm{C}$ & PPBC & http://www.plantphoto.cn/tu/1815135 \\
\hline K. delagoensis & $\begin{array}{l}\text { Gulangyu Island, Xiamen } \\
\text { (Fujian) }\end{array}$ & $24.45^{\circ} \mathrm{N}, 118.06^{\circ} \mathrm{E}$ & $\mathrm{W}$ & PPBC & $\begin{array}{l}\text { http://www.plantphoto.cn/tu/806892, } \\
\text { http://www.plantphoto.cn/tu/806870, } \\
\text { http://www.plantphoto.cn/tu/1017265 }\end{array}$ \\
\hline K. delagoensis & $\begin{array}{l}\text { University of Xiamen, } \\
\text { Xiamen (Fujian) }\end{array}$ & $24.44^{\circ} \mathrm{N}, 118.10^{\circ} \mathrm{E}$ & $\mathrm{C}$ & $\mathrm{CVH}$ & $\begin{array}{l}\text { AU 008751, 008752, and } 008753 \\
\text { [Herbărium specimen]; } \\
\text { http://Wwww.cvh.ac.cn/spm/AU/008751; } \\
\text { http://Wwww.cvh.ac.cn/spm/AU/008752; } \\
\text { http://\$www.cvh.ac.cn/spm/AU/008753 }\end{array}$ \\
\hline K. delagoensis & $\begin{array}{l}\text { Xiamen Botanical } \\
\text { Garden, Xiamen (Fujian) }\end{array}$ & $24.45^{\circ} \mathrm{N}, 118.10^{\circ} \mathrm{E}$ & $\mathrm{C}$ & $\mathrm{CFH}$ & $\begin{array}{l}\text { http:///Www.cfh.ac.cn/album/ShowPhoto.asp } \\
\text { x?photoid=11e08c1d-98bb-46ff-ba9e- } \\
\text { b14d09eaa7c8 }\end{array}$ \\
\hline K. delagoensis & $\begin{array}{l}\text { Dongzhaicun, Xianyou } \\
\text { (Fujian) }\end{array}$ & $25.26^{\circ} \mathrm{N}, 118.82^{\circ} \mathrm{E}$ & $\mathrm{W}$ & PPBC & http://www.plantphoto.cn/tu/651271 \\
\hline K. delagoensis & $\begin{array}{l}\text { Longhai, Zhangzhou } \\
\text { (Fujian) }\end{array}$ & $24.31^{\circ} \mathrm{N}, 118.01^{\circ} \mathrm{E}$ & $\mathrm{W}$ & PPBC & http://Wwww.plantphoto.cn/tu/1007036 \\
\hline K. delagoensis & $\begin{array}{l}\text { Guraozhen, Chaoyang } \\
\text { (Guangdong) }\end{array}$ & $23.34^{\circ} \mathrm{N}, 116.42^{\circ} \mathrm{E}$ & $\mathrm{W}$ & PPBC & http://㺼ww.plantphoto.cn/tu/262996 \\
\hline K. delagoensis & $\begin{array}{l}\text { Lutianzhen, Conghua } \\
\text { (Guangdong) }\end{array}$ & $23.81^{\circ} \mathrm{N}, 113.95^{\circ} \mathrm{E}$ & $\mathrm{C}$ & PPBC & $\begin{array}{l}\text { http:/席ww.plantphoto.cn/tu/1293361; } \\
\text { http://www.plantphoto.cn/tu/296526 }\end{array}$ \\
\hline K. delagoensis & $\begin{array}{l}\text { Gardens of Sun Yat-sen } \\
\text { University, Guangzhou } \\
\text { (Guangdong) }\end{array}$ & $23.10^{\circ} \mathrm{N}, 113.30^{\circ} \mathrm{E}$ & $\mathrm{C}$ & $\mathrm{CVH}$ & $\begin{array}{l}\text { IBSC } 0143075 \text { and PE } 00842704 \\
\text { [Herbărium specimen]; } \\
\text { http:///Www.cvh.ac.cn/spm/IBSC/0143075; } \\
\text { http://Www.cvh.ac.cn/spm/PE/00842704 }\end{array}$ \\
\hline K. delagoensis & $\begin{array}{l}\text { Haizhu District, } \\
\text { Guangzhou (Guangdong) }\end{array}$ & $23.11^{\circ} \mathrm{N}, 113.28^{\circ} \mathrm{E}$ & $\mathrm{W}$ & PPBC & $\begin{array}{l}\text { http://Wwww.plantphoto.cn/tu/1391866, } \\
\text { http://WWww.plantphoto.cn/tu/1288040, } \\
\text { http://WWww.plantphoto.cn/tu/603408 }\end{array}$ \\
\hline K. delagoensis & $\begin{array}{l}\text { Haizhu District, } \\
\text { Guangzhou (Guangdong) }\end{array}$ & $23.10^{\circ} \mathrm{N}, 113.32^{\circ} \mathrm{E}$ & $\mathrm{C}$ & PPBC & http:// $\underset{\substack{W \\
\zeta}}{W}$ ww.plantphoto.cn/tu/493582 \\
\hline K. delagoensis & $\begin{array}{l}\text { Huadu District, } \\
\text { Guangzhou (Guangdong) }\end{array}$ & $23.40^{\circ} \mathrm{N}, 113.21^{\circ} \mathrm{E}$ & $\mathrm{W}$ & PPBC & http:// \\
\hline K. delagoensis & Huangpu District, & $23.09^{\circ} \mathrm{N}, 113.39^{\circ} \mathrm{E}$ & $\mathrm{W}$ & PPBC & http://www.plantphoto.cn/tu/1787943 \\
\hline
\end{tabular}




\begin{tabular}{|c|c|c|c|c|c|}
\hline K. delagoensis & $\begin{array}{l}\text { Guangzhou (Guangdong) } \\
\text { South China Botanical } \\
\text { Garden, Guangzhou } \\
\text { (Guangdong) }\end{array}$ & $23.19^{\circ} \mathrm{N}, 113.36^{\circ} \mathrm{E}$ & $\mathrm{C}$ & PPBC & http://www.plantphoto.cn/tu/2089973 \\
\hline K. delagoensis & $\begin{array}{l}\text { Puning, Jieyang } \\
\text { (Guangdong) }\end{array}$ & $23.33^{\circ} \mathrm{N}, 116.16^{\circ} \mathrm{E}$ & $\mathrm{W}$ & PPBC & http://www.plantphoto.cn/tu/306683 \\
\hline K. delagoensis & $\begin{array}{l}\text { South Subtropical } \\
\text { Botanical Garden, } \\
\text { Mazhang (Guangdong) }\end{array}$ & $21.16^{\circ} \mathrm{N}, 110.27^{\circ} \mathrm{E}$ & $\mathrm{C}$ & $\mathrm{CFH}$ & $\begin{array}{l}\text { http://www.cfh.ac.cn/album/ShowPhoto.asp } \\
\text { x?photoid=4300e6cf-3a64-4835-9246- } \\
280 f 62448817\end{array}$ \\
\hline K. delagoensis & $\begin{array}{l}\text { Jieshizhen, Shanwei } \\
\text { (Guangdong) }\end{array}$ & $22.82^{\circ} \mathrm{N}, 115.83^{\circ} \mathrm{E}$ & $\mathrm{W}$ & PPBC & http://榇w.plantphoto.cn/tu/263359 \\
\hline K. delagoensis & $\begin{array}{l}\text { Waihu, Shanwei } \\
\text { (Guangdong) }\end{array}$ & $22.77^{\circ} \mathrm{N}, 115.52^{\circ} \mathrm{E}$ & $\mathrm{W}$ & PPBC & http:/虏www.plantphoto.cn/tu/596596 \\
\hline K. delagoensis & $\begin{array}{l}\text { Fairy Lake Botanical } \\
\text { Garden, Shenzhen } \\
\text { (Guangdong) }\end{array}$ & $22.58^{\circ} \mathrm{N}, 114.17^{\circ} \mathrm{E}$ & $\mathrm{C}$ & $\mathrm{PPBC}$ & http://wwww.plantphoto.cn/tu/1531470 \\
\hline K. delagoensis & $\begin{array}{l}\text { Longgang, Shenzhen } \\
\text { (Guangdong) }\end{array}$ & $22.62^{\circ} \mathrm{N}, 114.41^{\circ} \mathrm{E}$ & $\mathrm{W}$ & PPBC & http://Wwww.plantphoto.cn/tu/148668 \\
\hline K. delagoensis & $\begin{array}{l}\text { Longxianzhen, } \\
\text { Wengyuan (Guangdong) }\end{array}$ & $24.35^{\circ} \mathrm{N}, 114.13^{\circ} \mathrm{E}$ & $\mathrm{W}$ & PPBC & http://Wwww.plantphoto.cn/tu/1703110 \\
\hline K. delagoensis & $\begin{array}{l}\text { Huodaozhen, Zhaoqing } \\
\text { (Guangdong) }\end{array}$ & $22.86^{\circ} \mathrm{N}, 112.41^{\circ} \mathrm{E}$ & $\mathrm{C}$ & $\mathrm{PPBC}$ & http://www.plantphoto.cn/tu/1740778 \\
\hline K. delagoensis & $\begin{array}{l}\text { Former Residence of Sun } \\
\text { Yat-Sen, Zhongshan } \\
\text { (Guangdong) }\end{array}$ & $22.44^{\circ} \mathrm{N}, 113.53^{\circ} \mathrm{E}$ & $\mathrm{W}$ & PPBC & 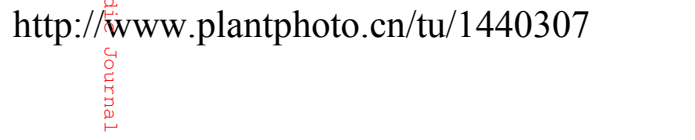 \\
\hline K. delagoensis & $\begin{array}{l}\text { Doumen District, Zhuhai } \\
\text { (Guangdong) }\end{array}$ & $22.22^{\circ} \mathrm{N}, 113.36^{\circ} \mathrm{E}$ & $\mathrm{W}$ & PPBC & http://wwww.plantphoto.cn/tu/814064 \\
\hline K. delagoensis & Guantian, Lipu (Guangxi) & $24.49^{\circ} \mathrm{N}, 110.47^{\circ} \mathrm{E}$ & $\mathrm{W}$ & $\mathrm{CFH}$ & 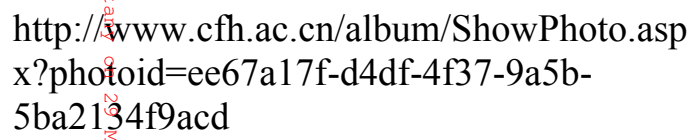 \\
\hline K. delagoensis & $\begin{array}{l}\text { Garden of the Institute of } \\
\text { Traditional Chinese } \\
\text { Medicine of Gemaling, }\end{array}$ & $22.84^{\circ} \mathrm{N}, 108.32^{\circ} \mathrm{E}$ & $\mathrm{C}$ & $\mathrm{CVH}$ & $\begin{array}{l}\text { GXM1006547 and } 006548 \text { [Herbarium } \\
\text { specimen]; } \\
\text { http://www.cvh.ac.cn/spm/GXMI/GXMI00 }\end{array}$ \\
\hline
\end{tabular}


http://www.cvh.ac.cn/spm/GXMI/GXMI00

K. delagoensis

Guangxi Medical

Botanical Garden,

Nanning (Guangxi)

K. delagoensis

K. delagoensis

K. delagoensis

K. delagoensis

K. delagoensis

K. delagoensis

K. delagoensis

K. delagoensis

K. delagoensis

K. delagoensis

K. delagoensis

K. delagoensis

\section{(Hainan)}

Xinlong Tropical

Botanical Garden,

Wanning (Hainan)

SAR)

Nanjing Botanical

Garden, Nanjing

(Jiangsu)

Gengzhuang, Heze

(Shandong)

Jinjiang District,

Chengdu (Sichuan) (Sichuan)

Dashu, Kaohsiung

(Taiwan)

Dashu, Kaohsiung

(Taiwan)

Jiaxian, Kaohsiung

(Taiwan)

Nanzhuang, Miaoli

County (Taiwan)

W Tai'an, Miaoli $22.85^{\circ} \mathrm{N}, 108.37^{\circ} \mathrm{E} \quad \mathrm{C}$

$20.04^{\circ} \mathrm{N}, 110.34^{\circ} \mathrm{E} \quad \mathrm{W}$

Yuen Long District, New

Territories (Hong Kong

Cycad Garden, Panzhihua $18.73^{\circ} \mathrm{N}, 110.20^{\circ} \mathrm{E} \quad \mathrm{C}$

$22.44^{\circ} \mathrm{N}, 114.01^{\circ} \mathrm{E} \quad \mathrm{W}$

$32.05^{\circ} \mathrm{N}, 118.83^{\circ} \mathrm{E} \quad \mathrm{C}$

$35.40^{\circ} \mathrm{N}, 115.43^{\circ} \mathrm{E}$

$30.58^{\circ} \mathrm{N}, 104.14^{\circ} \mathrm{E}$

$26.57^{\circ} \mathrm{N}, 101.72^{\circ} \mathrm{E}$

$22.71^{\circ} \mathrm{N}, 120.43^{\circ} \mathrm{E}$

$22.71^{\circ} \mathrm{N}, 120.41^{\circ} \mathrm{E}$

$23.08^{\circ} \mathrm{N}, 120.67^{\circ} \mathrm{E}$

$24.64^{\circ} \mathrm{N}, 121.02^{\circ} \mathrm{E}$

$24.39^{\circ} \mathrm{N}, 120.92^{\circ} \mathrm{E}$
$\mathrm{CFH}$

6548

http://www.cfh.ac.cn/album/ShowPhoto.asp

$\mathrm{x}$ ?photoid=20027a5f-06de-4c97-bbd0-

$1950 \mathrm{a} 0 \mathrm{f} 84 \mathrm{c} 83$

\section{This work HUTB-K1 [Herbarium specimen]}

CVH/PPB IBSC 0143076 [Herbarium specimen];

C http://www.cvh.ac.cn/spm/IBSC/0143076; http://Www.plantphoto.cn/tu/83951

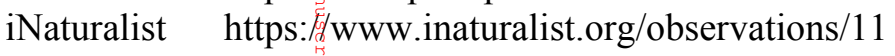
92734

CFH http://www.cfh.ac.cn/album/ShowPhoto.asp $\mathrm{x}$ ?photoid $=6 \mathrm{~b} 7287 \mathrm{ed}-4 \mathrm{cf} 2-45 \mathrm{f} 2-\mathrm{a} 84 \mathrm{f}$ $53360 \mathrm{a} 40 \mathrm{bd} 58$

PPBC http://www.plantphoto.cn/tu/2182628

PPBC http://Www.plantphoto.cn/tu/1785333

CFH http://wwww.cfh.ac.cn/album/ShowPhoto.asp $\mathrm{x}$ ?photoid=3bafb3bc-faf5-426d-a416fc78365d0395

TAIBIF http://taibif.tw/zh/occurrence/id/2477630

TAIBIF http://taibif.tw/zh/occurrence/id/2477629

TAIBIF http://taibif.tw/zh/occurrence/id/2469176

TAIBIF http://taibif.tw/zh/occurrence/id/2490656

TAIBIF http://taibif.tw/zh/occurrence/id/956754 


\begin{tabular}{|c|c|c|c|c|c|}
\hline & (Taiwan) & & & & \\
\hline K. delagoensis & Ren'ai, Nantou (Taiwan) & $24.02^{\circ} \mathrm{N}, 121.19^{\circ} \mathrm{E}$ & $\mathrm{W}$ & TAIBIF & http://taibif.tw/zh/occurrence/id/665465 \\
\hline K. delagoensis & $\begin{array}{l}\text { Changzhi, Pingtung } \\
\text { (Taiwan) }\end{array}$ & $22.74^{\circ} \mathrm{N}, 120.58^{\circ} \mathrm{E}$ & $\mathrm{W}$ & TAIBIF & http://taibif.tw/zh/occurrence/id/625738 \\
\hline K. delagoensis & $\begin{array}{l}\text { Changzhi, Pingtung } \\
\text { (Taiwan) }\end{array}$ & $22.73^{\circ} \mathrm{N}, 120.57^{\circ} \mathrm{E}$ & $\mathrm{W}$ & TAIBIF & http://taibif.tw/zh/occurrence/id/625739 \\
\hline K. delagoensis & $\begin{array}{l}\text { Donggang, Pingtung } \\
\text { (Taiwan) }\end{array}$ & $22.43^{\circ} \mathrm{N}, 120.48^{\circ} \mathrm{E}$ & $\mathrm{W}$ & TAIBIF & http://taibif.tw/zh/occurrence/id/778883 \\
\hline K. delagoensis & $\begin{array}{l}\text { Gaoshu, Pingtung } \\
\text { (Taiwan) }\end{array}$ & $22.77^{\circ} \mathrm{N}, 120.63^{\circ} \mathrm{E}$ & $\mathrm{W}$ & TAIBIF & http://Taibif.tw/zh/occurrence/id/620729 \\
\hline K. delagoensis & $\begin{array}{l}\text { Jiadong, Pingtung } \\
\text { (Taiwan) }\end{array}$ & $22.45^{\circ} \mathrm{N}, 120.57^{\circ} \mathrm{E}$ & $\mathrm{W}$ & TAIBIF & http:/歴aibif.tw/zh/occurrence/id/630902 \\
\hline K. delagoensis & $\begin{array}{l}\text { Linbian, Pingtung } \\
\text { (Taiwan) }\end{array}$ & $22.43^{\circ} \mathrm{N}, 120.51^{\circ} \mathrm{E}$ & $\mathrm{W}$ & TAIBIF & http:/委aibif.tw/zh/occurrence/id/630904 \\
\hline K. delagoensis & Neipu, Pingtung (Taiwan) & $22.64^{\circ} \mathrm{N}, 120.57^{\circ} \mathrm{E}$ & $\mathrm{W}$ & TAIBIF & $\begin{array}{l}\text { http://taibif.tw/zh/occurrence/id/779849; } \\
\text { http://taibif.tw/zh/occurrence/id/779848 }\end{array}$ \\
\hline K. delagoensis & $\begin{array}{l}\text { Xinyuan, Pingtung } \\
\text { (Taiwan) }\end{array}$ & $22.52^{\circ} \mathrm{N}, 120.47^{\circ} \mathrm{E}$ & $\mathrm{W}$ & TAIBIF & http://taibif.tw/zh/occurrence/id/778884 \\
\hline K. delagoensis & $\begin{array}{l}\text { Xinyuan, Pingtung } \\
\text { (Taiwan) }\end{array}$ & $22.49^{\circ} \mathrm{N}, 120.45^{\circ} \mathrm{E}$ & $\mathrm{W}$ & TAIBIF & http://taibif.tw/zh/occurrence/id/778886 \\
\hline K. delagoensis & Rende, Tainan (Taiwan) & $22.91^{\circ} \mathrm{N}, 120.24^{\circ} \mathrm{E}$ & $\mathrm{W}$ & TAIBIF & http://taibif.tw/zh/occurrence/id/535661 \\
\hline K. delagoensis & $\begin{array}{l}\text { National Taiwan } \\
\text { University Campus, } \\
\text { Taipei (Taiwan Island) }\end{array}$ & $25.02^{\circ} \mathrm{N}, 121.54^{\circ} \mathrm{E}$ & $\mathrm{C}$ & TAIBIF & $\begin{array}{l}\text { TAI } 168840 \text { [Herbarium specimen]; } \\
\text { http://taibif.tw/zh/occurrence/id/53283 } \\
\end{array}$ \\
\hline K. delagoensis & $\begin{array}{l}\text { Yamingshan National } \\
\text { Park, Taipei/New Taipei } \\
\text { (Taiwan) }\end{array}$ & $25.19^{\circ} \mathrm{N}, 121.56^{\circ} \mathrm{E}$ & $\mathrm{W}$ & Hua (2004) & 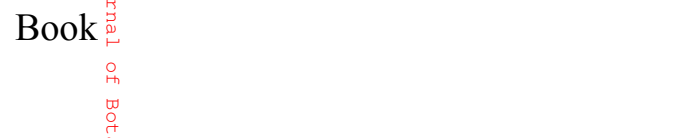 \\
\hline K. delagoensis & $\begin{array}{l}\text { Tamsui River Mangrove } \\
\text { Conservation Area, } \\
\text { Tamsui (Taiwan) }\end{array}$ & $25.16^{\circ} \mathrm{N}, 121.46^{\circ} \mathrm{E}$ & $\mathrm{W}$ & --- & $\begin{array}{l}\text { https:/195b6d4dc83299ba2419c3ab9236f20c } \\
\text { 1aee2èc11.googledrive.com/host/0ByHgwY } \\
\text { 2tmBQ̈JZGJqTkI4Ym91OTA/Travels5/t14 } \\
\text { 1.htm }\end{array}$ \\
\hline K. delagoensis & $\begin{array}{l}\text { Taida Redai Botanical } \\
\text { Garden, Binhai (Tianjin }\end{array}$ & $39.03^{\circ} \mathrm{N}, 117.71^{\circ} \mathrm{E}$ & $\mathrm{C}$ & PPBC & http://Wwww.plantphoto.cn/tu/1531452 \\
\hline
\end{tabular}




\begin{tabular}{llllll}
\hline K. delagoensis & $\begin{array}{l}\text { Municipality) } \\
\text { Xiqing District, Tianjin } \\
\text { (Tianjin Municipality) }\end{array}$ & $39.14^{\circ} \mathrm{N}, 117.01^{\circ} \mathrm{E}$ & $\mathrm{C}$ & $\mathrm{PPBC}$ & http://www.plantphoto.cn/tu/1831698 \\
K. delagoensis & $\begin{array}{l}\text { Kunming Botanical } \\
\text { Garden, Kunming } \\
\text { (Yunnan) }\end{array}$ & $25.14^{\circ} \mathrm{N}, 102.74^{\circ} \mathrm{E}$ & $\mathrm{C}$ & $\mathrm{PPBC}$ & $\mathrm{http} / / /$ www.plantphoto.cn/tu/1046878 \\
& & & & \\
\hline
\end{tabular}

${ }^{1}$ The herbarium specimen has no leaves, and it has been labeled as “ $K$. gremontianum". Since $K$. delagoensis is also present in the same locality (Gulangyu Island, Xiamen, Fujian), this specimen might actually be K. delagoensis.

${ }^{2}$ The herbarium specimen has no leaves, and it has been labeled as "K. gremontianum".

${ }^{3}$ Although the herbarium specimen has both flowers and leaves, it is not well preserved. Although it is that it may correspond to either $K$. daigremontiana or $K . \times$ houghtonii.

${ }^{4}$ Although the herbarium specimen is not well preserved (and it has no flowers), we do not believe that it corresponds to Bryophyllum pinnatum (as labeled). Instead, this specimen might actually be either $K$. daigremontiana or $K . \times$ houghtonii.

${ }^{5}$ There is no information in the label about the exact location of the collected individual (just "Forestry" Bureau" and "Xinjiang").

\section{References}

Hong Kong Herbarium 2004. Check List of Hong Kong Plants 2004. - Agriculture, Fisheries and Conservation Department, the Government of Hong Kong Special Administrative Region, Hong Kong.

Hu, X.-H. et al. 2011. Investigation and analysis on alien plants in Bawangling National Nature Resểrve in Hainan Province. - J. Jinggangshan Univ. (Nat. Sci.) 32: 131-136 (in Chinese).

Hua, P.-J. 2004. The exotic plant research in Yamingshan National Park. -Yangmingshan Nation̆al Park Headquarters, Yangmingshan (in Chinese).

Wu, L. 2012. Research on invasion risk of naturalized plants in Mount Huang Scenic Area. - Master Thesis, Anhui Agricultural University, Hefei (in Chinese). 